\title{
NETLEAF HACKBERRY SEEDS PLANTED NEAR BOULDERS IN THE FOOTHILLS OF THE WASATCH MOUNTAINS: GERMINATION, SURVIVAL, AND PATTERNS OF ESTABLISHMENT
}

\author{
Michael T. Stevens ${ }^{1,2}$, Daniel L. Holland ${ }^{1}$, Nathan V. Tanner ${ }^{1}$
}

\begin{abstract}
Netleaf hackberry (Celtis reticulata) is a deciduous shrub native to the southwestern United States and northern Mexico. Previous field observations have shown limited numbers of juvenile hackberries in the wild. This could be due to low germination and survival rates, but field germination trials have not been done. In the foothills of the Wasatch Mountains in Utah, hackberry shrubs have been shown to grow in association with boulders, likely using them as nurse objects. This experimental study field-tested germination and survival rates around boulders in this area. We located 26 boulders and planted 25 hackberry seeds on the north, west, south, and east sides of each boulder ( $n=2600$ seeds). In the following year, we counted the number of hackberry seeds that had germinated and become established near each of the boulders' sides. Overall, germination rates were extremely low, with only $55(2.1 \%)$ of the planted seeds germinating and only $19(0.7 \%)$ persisting until the end of the growing season. Among the few seedlings that survived, we found even fewer on the east sides of boulders. In the west-facing Wasatch Range, the east side of a boulder typically has a higher elevation than the other sides of a boulder and may expose hackberry seedlings to excessively dry conditions and erosion as precipitation collects in the lower areas around a boulder. Additionally, the microclimate-stabilizing benefits of a boulder may be limited for plants growing on the east side of a boulder because the morning sun is blocked by the Wasatch Mountains. The highest rates of germination were found on the comparatively shady and moist north sides of boulders where greater plant competition may limit long-term establishment of hackberry seedlings. Our study furthers our understanding of nurse associations in semiarid environments and can be applied by land managers seeking to utilize hackberry in site restorations.
\end{abstract}

Resumen.-Celtis reticulata es un arbusto deciduo nativo del suroeste de Estados Unidos y del norte de México. Observaciones previas de campo han mostrado un número limitado de C. reticulata juveniles silvestres. Esto podría deberse a las bajas tasas de germinación y supervivencia, pero no se han realizado pruebas de germinación en campo. En las laderas de las Montañas Wasatch en Utah, se ha visto que los arbustos de esta planta crecen en asociación con peñascos, probablemente como protección. En este estudio realizamos un experimento de manipulación en campo para evaluar la germinación y las tasas de supervivencia en torno a los peñascos en esta área. Localizamos 26 peñascos y plantamos 25 semillas en los lados norte, oeste, sur y este de cada peñasco $(n=2600$ semillas). Al año siguiente, contamos el número de semillas germinadas y que se habían establecido cerca de los peñascos de cada lado. En general, las tasas de germinación fueron extremadamente bajas, con sólo 55 (2.1\%) de las semillas germinando y sólo $19(0.7 \%)$ persistiendo hasta el final de la temporada de crecimiento. Entre las pocas plántulas que sobrevivieron, encontramos todavía un número menor en los lados este de los peñascos. En la Cordillera Wasatch orientada hacia el oeste, el lado este del peñasco tiene, por lo general, una elevación mayor comparada con los otros lados y puede exponer las plántulas a condiciones excesivamente secas y a erosión, ya que la precipitación se acumula en la zona más baja alrededor del peñasco. Además, los beneficios de la estabilización del microclima del peñasco pueden ser limitados por las plantas que crecen en el lado este del peñasco porque el sol de la mañana está bloqueado por las Montañas Wasatch. Las mayores tasas de germinación se dieron en los lados norte de los peñascos, son comparativamente los de más sombra y humedad, donde una mayor competencia entre plantas puede limitar el establecimiento a largo plazo de las plántulas de C. reticulata. Nuestro estudio refuerza nuestra comprensión de las asociaciones de protección en ambientes semiáridos y puede ser aplicado por los gestores que buscan utilizar plantas de Celtis reticulata en áreas de restauración.

Native to semiarid areas in the southwestern United States and northern Mexico, netleaf hackberry (Celtis reticulata) is a deciduous shrub in the Cannabaceae family (Sytsma et al. 2002). It produces fruits that are an important source of food for birds (Hayward 1948) and small mammals (DeBolt and McCune 1995b) that likely aid in its seed dispersal; however, newly established stands of hackberry are uncommon (DeBolt and McCune 1995a). The dearth of juvenile hackberry could be due to low germination and survival rates. In the laboratory, seed germination rates tend to be very low (Bonner 1974, DeBolt 1992), and 
data are not available on hackberry germination trials in the field. In fact, DeBolt and McCune (1995b) highlighted the need for experimental study plots in the field.

In the wild, germination and survival rates of hackberry could be influenced by specific environmental conditions required for establishment associated with aspect (Tisdale 1986), substrate (DeBolt and McCune 1995a), or the interaction between aspect and substrate (Argyle and Stevens 2013). Hackberries tend to be found on warm sites with southern exposure (Tisdale 1986), in rocky areas (DeBolt and McCune 1995a), and especially on the south sides of boulders (Argyle and Stevens 2013). Boulders can act as microclimate-stabilizing nurse objects (Kleier and Lambrinos 2005) that can be particularly important for the survival of juvenile plants (Sterling et al. 1984).

We sought to field-test germination and survival rates of hackberry in the xeric foothills of the Wasatch Mountains of Utah where hackberry is a common member of the northern mountain brush community and is found growing up to $1800 \mathrm{~m}$ in elevation (Van Buren et al. 2011). Because previous observational work in this area has shown a hackberry-boulder association (Argyle and Stevens 2013), we designed the current study to determine whether observed patterns of distribution among mature shrubs are aligned with germination and survival rates of experimentally planted seeds. With this study we sought to answer the following questions: (1) What is the germination and survival rate of hackberries planted in the field? (2) Do patterns of establishment differ when hackberry seeds are planted next to one side of a boulder or another?

\section{METHODS}

Our study site is located in the foothills of the Wasatch Mountains in Utah at the base of Y Mountain, directly east of the city of Provo, Utah (Fig. 1), and near the study sites of Hayward (1948) and Argyle and Stevens (2013). The area has an average annual temperature of $11.9^{\circ} \mathrm{C}$ and receives an average of $50.2 \mathrm{~cm}$ of precipitation per year (1981-2010; NOAA-NWS 2010). In this area, the native shrub netleaf hackberry (Celtis reticulata) is common and frequently grows in association with boulders (Argyle and Stevens 2013).
On 3 October 2014, students in Utah Valley University's Plant Ecology class visited the field site to select naturally occurring boulders and collect hackberry fruits for the study. Boulders were selected for this study if they (1) were at least $0.5 \mathrm{~m}$ along one dimension, (2) did not have hackberries or other shrubs growing within $0.5 \mathrm{~m}$, and (3) were at least $1 \mathrm{~m}$ away from any neighboring boulders. The exact location of each boulder was determined using GPS. After reviewing the possible boulders that fit our 3 criteria, we selected and marked 26 for the study (Fig. 1). On 16 October, in preparation for planting, we removed plant competition from around each of the 26 boulders in an area that extended $0.3 \mathrm{~m}$ from the edges of each boulder.

The collected fruits were stored in paper bags for 1 day, then placed on an elevated screen to air-dry at room temperature. After nearly a month, we soaked the air-dried fruits in a 1:100 bleach solution $(10 \mathrm{~mL}$ of bleach in $1000 \mathrm{~mL}$ of distilled water) for $15 \mathrm{~min}$ to destroy any pathogens (DeBolt 1992). The intact fruits (pulp retained) were then rinsed in tap water and soaked for $72 \mathrm{~h}$ in distilled water at room temperature. This process of fermentation was used to mimic the conditions of a digestive tract of a bird or mammal (DeBolt 1992). Fruits that floated during this process were removed from the experiment (Leon 2014). We planted hackberry seeds around the 26 previously selected boulders on 30-31 October 2014. Twenty-five seeds were planted on the north, west, south, and east sides of each boulder $(n=100$ seeds per boulder; 2600 seeds total). Directions were determined with a compass. The 25 seeds were planted in a $5 \times 5$ array using a $0.25 \times 0.25$-m grid such that each seed was $5 \mathrm{~cm}$ away from its nearest neighbors. The seeds were then covered with $1.5 \mathrm{~cm}$ of the locally occurring soil (Bonner 1974) and cold stratified by naturally occurring winter conditions.

After planting in fall 2014, we visited the site informally in the spring of 2015 looking for signs of germination. We formally sampled the population on 29 May, 12 June, 1 July, 22 July, 24 August, and 2 November 2015 by counting the number of hackberry seedlings growing near the sides of each boulder. We used chi-square tests in JMP version 12.1.0 (SAS Institute, Inc. 2015) to determine whether the 


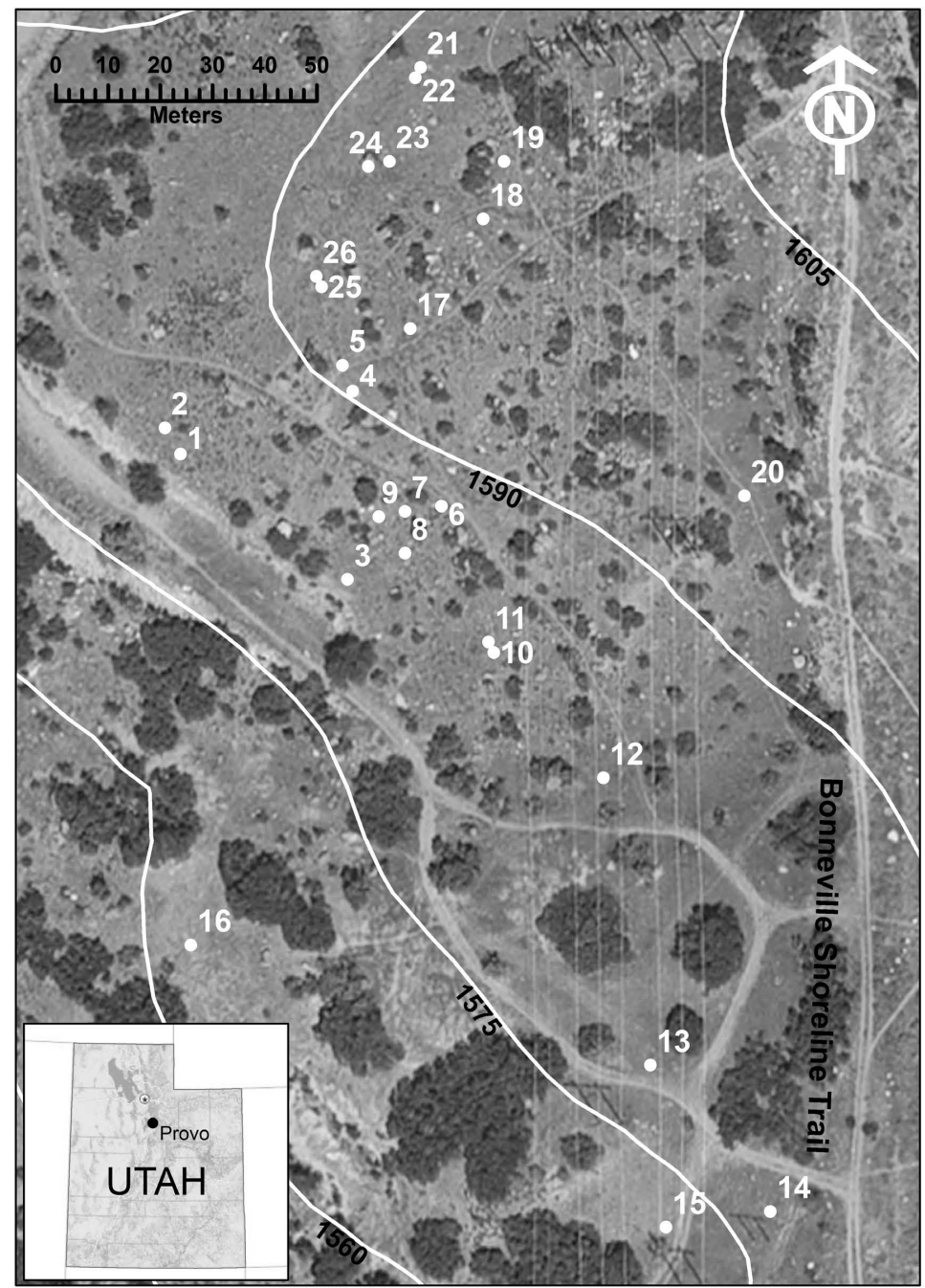

Fig. 1. An overhead view of the locations of the 26 boulders used in this study in the foothills of the Wasatch Mountains east of Provo, Utah. Contour lines show elevations in meters at 15-m intervals.

number of hackberry seedlings differed on one side of a boulder versus another.

\section{RESULTS}

We first observed 2 hackberry seedlings on 13 May 2015, with readily identifiable true leaves and very characteristic obcordate cotyledons with cleft apices. On this date, we also observed possible hackberry seedlings identified by their hypocotyl hooks at the soil surface. Because hackberry germination is epigeal (Bonner 1974, DeBolt 2004), we waited until late in May to begin formally sampling our study population. This additional time allowed us to conclusively identify hackberry seedlings after the emergence of their characteristic cotyledons.

On 29 May, germination rates were extremely low overall. Forty-one of 2600 seeds (1.6\%) had germinated and survived to be counted. By this date, fewer seeds $(0.6 \%)$ on the east sides of boulders had germinated, and more seeds $(2.6 \%)$ on the north sides of boulders had germinated compared to the number of seeds that had germinated on the west and south sides of boulders $\left(\chi^{2}=8.463\right.$, $\mathrm{df}=3$, $P=0.037$; Fig. 2).

By 12 June, the number of seedlings had increased to 48 . This date had the highest 


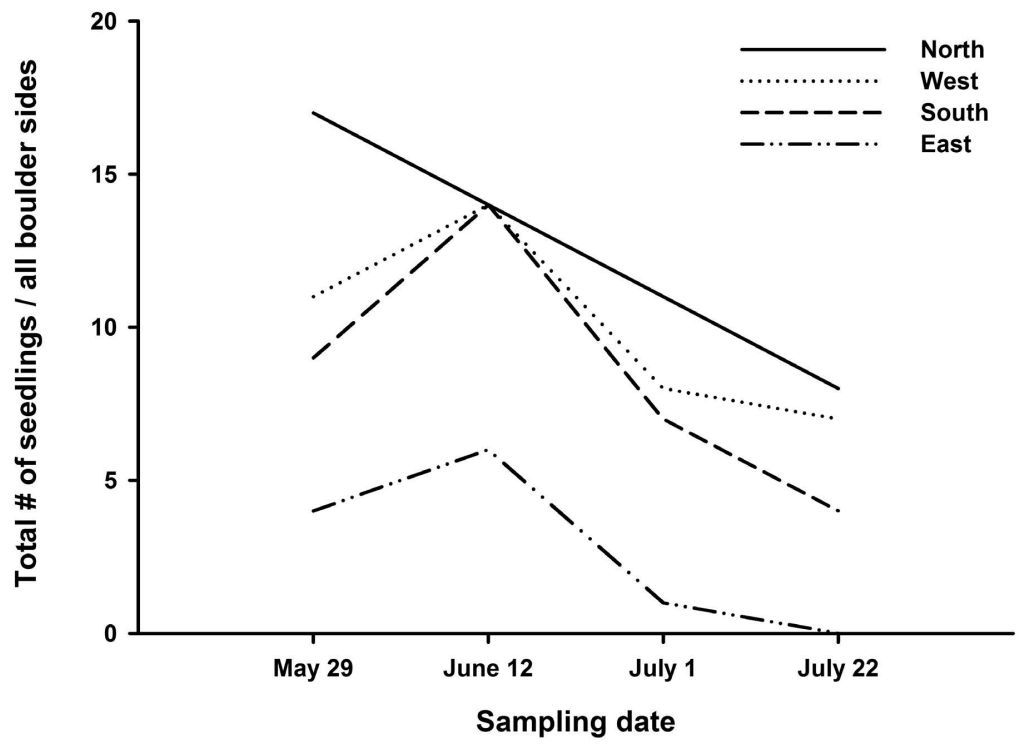

Fig. 2. The total numbers of hackberry seeds that germinated and seedlings that survived on 4 sampling dates in 2015. Hackberry seeds were planted on the north, west, south, and east sides of boulders $(n=26)$ in the foothills of the Wasatch Mountains east of Provo, Utah. The total numbers of seedlings on each side of the boulders differed statistically on 29 May $\left(\chi^{2}=8.463, \mathrm{df}=3, P=0.037\right), 1$ July $\left(\chi^{2}=7.815, \mathrm{df}=3, P=0.050\right)$, and 22 July $\left(\chi^{2}=8.158, \mathrm{df}=3, P=\right.$ $0.043)$. The number of surviving seedlings was unchanged from 22 July to 2 November.

number of seedlings for all boulder sides (i.e., west, south, east) except for the north sides that had the highest number of seedlings on 29 May (Fig. 2). Between 29 May and 12 June, the north sides gained 1 additional seedling and lost 4 to mortality, the west sides gained 6 additional seedlings and lost 3 to mortality, the south sides gained 5 additional seedlings, and the east sides gained 2 additional seedlings. In total, $55(2.1 \%)$ of the experimentally planted seeds germinated over the course of the study.

Seedling survival rates were much higher than germination rates, but were still low. Of the 55 seeds that germinated, $19(34.6 \%)$ survived through to 2 November. It is important to note, however, that the 19 hackberry seedlings that became established represent only $0.7 \%$ of the 2600 seeds that were planted.

Although only a small number of seedlings survived, some interesting patterns emerged. Seedlings were less likely to become established on the east sides and more likely to become established on the north sides of boulders. This pattern was evident on 1 July $\left(\chi^{2}=7.815\right.$, df $\left.=3, P=0.050\right)$ and 22 July $\left(\chi^{2}=8.158, \mathrm{df}=3, P=0.043\right.$; Fig. 2$)$ and continued through 2 November, with all of the seedlings present on 22 July surviving.
Because of the large number of zeros in our data set, we used box plots to show the median number of seedlings on each of side of the 26 boulders by direction for each sampling date (Fig. 3). This presentation of data allowed us to highlight the variation across our study site with respect to individual boulder sides. The east sides of boulders consistently had lower maximum numbers of hackberry seedlings per side, as well as lower 90th and 75th quartile values (Fig. 3).

\section{Discussion}

Germination

Our finding of extremely low germination rates in the field $(2.1 \%)$ is corroborated by rates found in the laboratory (1.0\%) using similarly processed seeds (i.e., fermented, nonscarified, with pulps retained; DeBolt 1992). DeBolt (1992) recommended planting minimally processed seeds because their more laboriously processed seeds (i.e., scarified and depulped) also had low rates of germination.

Interestingly, although our rate of germination was extremely low, it was slightly more than double the rate of DeBolt's (1992) laboratory trials. This is surprising given that our 

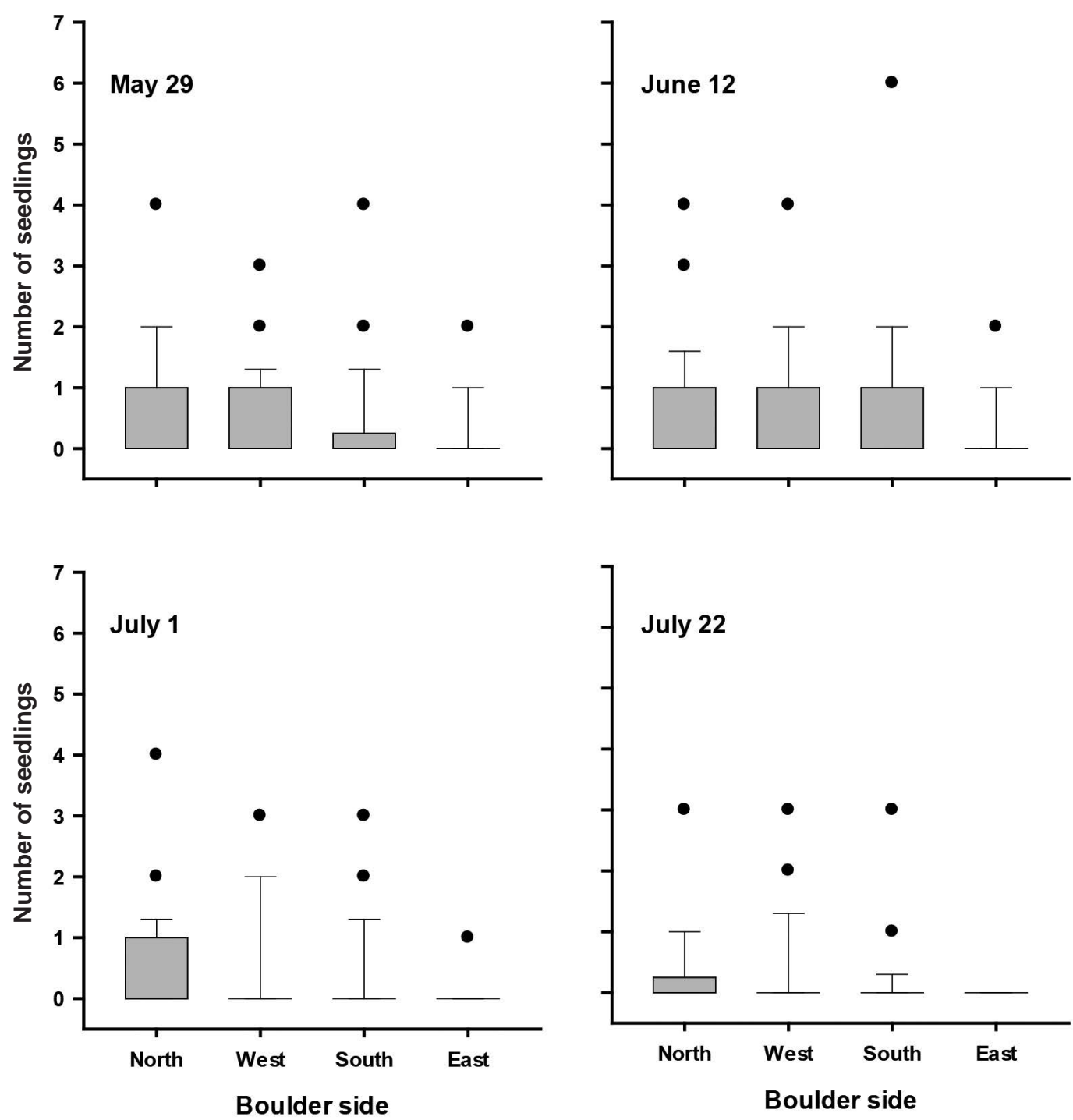

Fig. 3. Box plots for each sampling date showing the variation in the number of seedlings on each individual boulder side by direction $(n=26$ boulders and 104 boulder sides). Note that the bottom line of each of the vertical bars represents the minimum number of seedlings on an individual boulder side and in many cases also represents the 25th quartile, median, and 75th quartile. For the east sides of boulders on 1 July, it also represents the 90th quartile, and on 22 July, the maximum number of seedlings found per individual boulder side.

field-tested seeds were subject to natural levels of seed predation and/or removal by animals. Even with the possibilities for seed predation, our higher germination rate could actually be due to the benefits of a natural field setting (that included boulders). In their observational study, DeBolt and McCune (1995a) found the highest densities of juvenile hackberries in areas characterized by surface rocks. Additionally, our higher rate of germination in the field could be due to the effects of cold stratification. Our hackberry seeds were naturally cold stratified by winter conditions, whereas DeBolt (1992) did not cold stratify seeds in order to avoid problems with fungal contamination in the laboratory.

That we found the lowest rates of germination on the east sides of boulders is supported by the observational studies of Argyle and Stevens (2013), who found fewer hackberry 
shrubs growing on the east and north sides of boulders in Utah, and by DeBolt and McCune (1995a), who reported infrequently finding hackberry growing on east- or north-facing slopes in Idaho. Our finding of the highest germination rates on the north sides of boulders is not in-line with the findings of these 2 observational studies of mature hackberries and may be a short-lived phenomenon related to hackberry seedlings. In fact, interspecific competition may limit the persistence of hackberries that germinate on northerly aspects. For instance, DeBolt and McCune (1995a) stated that slow-growing and frost-sensitive hackberries may not be able to compete on north-facing slopes that are generally covered by fast-growing and frost-tolerant species in the Northern Hemisphere.

\section{Survival}

Although DeBolt and McCune (1995a) observed extremely high first-year seedling mortality in the field, we found reasonable rates of survival from germination to the end of the growing season among the very few hackberries that actually germinated. Our differing results could be due to the manipulative nature of our study. Instead of observing stands of hackberry in the wild like DeBolt and McCune (1995a) did, we frequently visited marked individual seedlings that had been purposely planted next to boulders at a field site where hackberry shrubs grow naturally. Under the right conditions, the survival rate of hackberry seedlings may be higher than previously reported, although it is important to note that our rates of germination were still extremely low.

\section{Patterns of Establishment}

The fact that we found even lower germination and survival rates on the east sides of boulders is likely due to the general slope and aspect of the Wasatch Mountains and their effects on water flow and heat transfer around a boulder. On the west-facing Wasatch Mountains, the east sides of boulders are typically higher in elevation than the other sides of a boulder. In response to gravity, water will drain from the higher east sides of boulders to the lower sides of boulders, leaving the east sides of boulders especially dry in a region that already receives limited precipitation. Heth (1981) indicated that local topography becomes especially important under arid and semiarid conditions. The higher east side of a boulder is also more prone to erosion than other sides of a boulder, and intense precipitation events, such as summer thunderstorms, could cause hackberry seeds (and even seedlings) on the east sides of boulders to be carried downhill in the runoff from storms. Additionally, because the Wasatch Mountains block the morning sun, the microclimate-stabilizing effects on the east side of a boulder may be limited because there is less heat absorbed and available to radiate later in the day (Jury and Bellantuoni 1976). This may be particularly important for germination and survival of a shrub that favors warm sites (Tisdale 1986, DeBolt and McCune 1995a).

In addition to finding fewer hackberries that had germinated and become established on the east sides of boulders, we found the highest number of seedlings on the north sides of boulders over the course of one growing season. Given more time, the effects of interspecific plant competition on the north sides of boulders could limit the long-term survival of hackberries in the comparatively shady, moist, and competitive microclimates with northern exposures (DeBolt and McCune 1995a). If this is the case, the patterns we observed for experimentally planted seeds and seedlings over one growing season could eventually be more in-line with the patterns observed by DeBolt and McCune (1995a) and Argyle and Stevens (2013), who commonly found mature hackberry shrubs occupying south- and west-facing slopes and the south and west sides of boulders, respectively.

\section{Conclusions}

Consistent with DeBolt and McCune's (1995b) recommendations for using hackberry for restoration efforts, we advocate planting large quantities of seeds in a nursery and then transplanting seedlings to suitable locations in the field. This is because of hackberry's extremely low germination rates both in the laboratory (DeBolt 1992) and in our manipulative field trials. Whereas DeBolt and McCune (1995b) recommend planting hackberry seedlings in rocky sites, we, more specifically, recommend taking advantage of boulders as nurse objects and establishing seedlings near the appropriate sides of boulders, taking into account the general topography and aspect of the site. 


\section{ACKNOWLEDGMENTS}

We thank Gary Stone and Daniel Smith for granting us permission to conduct research on their private land. Students in the 2014 Plant Ecology class at Utah Valley University (UVU) helped collect hackberry fruits and select boulders. Additionally, UVU students Randon Leavitt and Lisa Rasmussen helped finalize boulder selection; Preston Ethington, Sarah Heelis, and Gabrielle Thomas assisted with the removal of plant competition from around the boulders; and Matt Wang produced the map (Fig. 1). Insightful comments from an anonymous reviewer and the associate editor helped improve this manuscript.

\section{Literature Cited}

Argyle, A., AND M.T. Stevens. 2013. Influence of boulders on netleaf hackberry (Celtis reticulata) growth and distribution in the Wasatch foothills. Western North American Naturalist 73:525-529.

BonneR, F.T. 1974. Celtis L. hackberry. Pages 298-300 in C.S. Shopmeyer, editor, Seeds of woody plants in the United States. Handbook 450. U.S. Department of Agriculture, Washington, DC.

DeBolt, A.M. 1992. The ecology of Celtis reticulata Torr. (netleaf hackberry) in Idaho, Master's thesis, Oregon State University, Corvallis, OR. $161 \mathrm{pp}$.

DeBolt, A.M. 2004. Celtis reticulata Torr. netleaf hackberry. Pages 167-169 in J.K. Francis, editor, Wildland shrubs of the United States and its territories: thamnic descriptions. General Technical Report IITF-GTR-26, Volume 1. U.S. Department of Agriculture, San Juan, PR.

DeBolt, A.M., AND B. McCune. 1995a. Ecology of Celtis reticulata in Idaho. Great Basin Naturalist 55: 237-248.

DeBolt, A.M., AND B. McCune. 1995b. Is netleaf hackberry a viable rehabilitation species for Idaho rangelands? Pages 305-309 in B.A. Roundy, E.D. McArthur, J.S. Haley, and D.K. Mann, compilers,
Proceedings: wildland shrub and arid land restoration symposium. General Technical Report INT-GTR315, U.S. Department of Agriculture, Ogden, UT.

HaYwaRD, C.L. 1948. Biotic communities of the Wasatch chaparral, Utah. Ecological Monographs 18:473-506.

Heth, D. 1981. Planting trees for the reclamation of desert lands. Arboricultural Journal 5:81-105.

Jury, W.A., AND B. Bellantuoni. 1976. Heat and water movement under surface rocks in a field soil: 1 . Thermal effects. Soil Science Society of America Journal 40:505-509.

Kleier, C., And J.G. Lambrinos. 2005. The importance of nurse associations for three tropical alpine life forms. Arctic, Antarctic, and Alpine Research 37:331-336.

LEON, A. 2014. How to sprout a hackberry seed. [Accessed 12 October 2014]. http://homeguides .sfgate.com/sprout-hackberry-seed-51327.

[NOAA-NWS] National OCEANIC and ATMOSPheriC Administration-National Weather Service. 2010. National Weather Service Forecast Office, Salt Lake City, UT; [accessed 28 June 2013]. http://www.nws .noaa.gov/climate/xmacis.php?wfo $=$ slc

SAS InstituTe, INC. 2015. JMP Version 12.1.0. SAS Institute, Inc., Cary, NC.

Sterling, A., B. Peco, M.A. Casado, E.F. Galiano, and F.D. PINEDA. 1984. Influence of microtopography on floristic variation in the ecological succession in grassland. Oikos 42:334-342.

Sytsma, K.J., J. Morawetz, J.C. Pires, M. Nepokroeff, E. Conti, M. Zjhra, J.C. Hall, and M.W. Chase. 2002. Urticalean rosids: circumscription, rosid ancestry, and phylogenetics based on rbcL, trnL-F, and ndhF sequences. American Journal of Botany 89:1531-1546.

Tisdale, E.W. 1986. Canyon grasslands and associated shrublands of west-central Idaho and adjacent areas. Bulletin No. 40. Forest, Wildlife and Range Experiment Station, University of Idaho, Moscow, ID.

Van Buren, R., J.G. Cooper, L.M. Shultz, and K.T. HaRPer. 2011. Woody plants of Utah: a field guide with identification keys to native and naturalized trees, shrubs, cacti, and vines. Utah State University Press, Logan, UT.

Received 13 June 2016 Accepted 5 October 2016 